\title{
A Course Guideline for the Design of Specialized English Courses for Non-commissioned Officers from the Perspective of Content-based Instruction
}

\author{
Wenhui Hao ${ }^{1, *}$ Yucheng $\mathrm{Zhou}^{1}$ Mei Song ${ }^{1}$ Shasha $\mathrm{Wu}^{1}$ \\ ${ }^{1}$ College of Information and Communication, National University of Defense Technology, Xi'an, Shaanxi \\ 710106, China \\ "Corresponding author. Email: hwhada@sina.com
}

\begin{abstract}
Based on the perspective of Content-Based Instruction (CBI), this paper attempts to provide a guidance method for the design of specialized English courses for non-commissioned officers. By sorting out the concept of CBI and combining with the teaching practice of ESP (English for Specific Purposes) curriculum design, this article proposes a curriculum design framework for professional English teaching, and discusses how to construct a teaching model based on the CBI theme in the non-commissioned English classroom teaching from the dimensions of curriculum objectives, teaching models, teaching methods, teaching evaluation and reflection.
\end{abstract}

Keywords: Content-based instruction, ESP, Theme-based approach, Teaching design.

\section{INTRODUCTION}

In recent years, the reform of college English teaching has been carried out in full swing in China. One of the highlights of the University English Teaching Guide issued in 2017 is to strengthen the organic combination of language teaching and professional teaching, and strengthen the teaching activities of specialized English [1]. The CBI emphasizes the integration of professional teaching and language teaching, that is, learning language in professional learning [2], so it is a good concept and method for specialized English teaching. The effective implementation of CBI can not only improve the professional quality of noncommissioned officers, but also improve their comprehensive English application ability. Based on the CBI teaching method, this thesis comprehensively analyzes the core factors in the design of specialized English courses: needs analysis, course objectives, course goals, teaching models, teaching methods, evaluation and reflection, and proposes a sample of the framework of specialized English courses. As a starting point for the discussion, this article first sorts out the concepts of CBI teaching method and the practices of specialized English teaching reform in recent years.

\section{CONCEPTS OF CBI TEACHING METHOD AND PRACTICES OF SPECIALIZED ENGLISH TEACHING REFORM}

\subsection{Concepts of CBI Teaching Method}

CBI, which stands for Content-Based Instruction, is a teaching method that integrates students' language courses and subject content. Originating from second language teaching in Canada in the 1960s, it was used to teach foreign students or immigrants in the environment of target language, and later was widely used in the second language acquisition environment. According to the theory of second language acquisition, learners must rely on a certain language environment to learn a foreign language and use the language through extensive contact with the corpus of the target language, so as to improve their language competence [3]. CBI fits this idea of acquiring language through learning content and knowledge, and is a comprehensive method that emphasizes both language skills and subject contents. However, due to differences in the overall understanding of language learning, subject contents learning, and how to balance the two, scholars also have many 
different definitions of the concept of CBI. For example, Krashen proposed that in the CBI classroom, students can gain language skills while learning subject knowledge [4]; Davies believes that CBI is a teaching method, which emphasizes subject contents learning rather than pure language learning [5]; Dupuy pointed out that CBI is a teaching approach, which uses target language to teach professional subject content, so that students can not only master professional subject knowledge, but also acquire the target language. It is a highly efficient foreign language teaching approach that combines professional content and language acquisition; Richards proposed that $\mathrm{CBI}$ is content teaching and organize teaching activities based on students' learning content, rather than teaching activities based on language teaching or syllabus [6]. From the perspective of the definition of CBI by academic scholars, many scholars regard CBI as a teaching method or teaching approach which integrate subject knowledge into the teaching of the target language

\subsection{Practices of Specialized English Teaching Reform}

From the theoretical background of CBI, it is not difficult to see that this method can achieve the dual goals of subject knowledge teaching and English language ability training, and can promote the reform of specialized English teaching. In fact, many scholars have done a lot of research in this aspect. For example, in the CBI teaching practice, according to the teaching aim, teaching activities, and different requirements such as study materials, three typical types are derived, namely: themebased approach, which is a mode for language teachers to select different professional themes and organize professional teaching according to the professional needs of students; sheltered-content courses, a teaching mode in which professional teachers who know the major choose suitable professional materials according to students' professional quality and organize teaching activities; adjunct course, a teaching mode in which language teachers and professional teachers cooperate with each other and jointly undertake the teaching tasks of language and specialized courses. Although these three models have different focuses, they all have the following four basic characteristics: taking subject knowledge as the core; using real language materials; learning new information; making sure curriculum settings meet the needs of different groups [8]. It should be said that the three teaching modes of CBI are in many ways consistent with the three basic principles of ESP teaching, namely, the principle of authenticity, the principle of studentcenteredness, and the principle of needs analysis. The biggest feature of CBI is that it emphasizes the learning of language in professional learning or specialized English teaching

In order to make CBI more effectively applied to teaching practice, Stoller also proposed $6 \mathrm{~T}$ methods, namely theme, text, topic, thread, task and transition [9]. Theme is the starting point and center of the curriculum design; Text is the representative learning material related to the theme in any form; Topic is the refinement and classification of the theme, which supports the content of the theme from many aspects; Thread and Transitions are the connecting means, through which natural transitions and connections are generated between topics. Tasks are instructional activities and designs that make learning work. It is worth noting that when choosing a topic, we must follow the needs, interest and level of students, as well as the teacher's ability to control the topic, and pay attention to the length and continuity of the material when choosing the text.

Many domestic scholars have also done a lot of empirical research in this respect and have achieved certain results. In the early years, Cao Xianwen [10] of Nanjing University and Cai Yuesheng [11] of Huazhong Agricultural University used different CBI teaching models and combined students' professional knowledge to practice CBI teaching and achieved good teaching results. In recent years, there have been more and more researches on CBI teaching. Zhang Wenjun proposed a teaching design case of E-Business English based on CBI teaching [12]. Yuan Pinghua of Nanjing University explored the impact of CBI on students' critical thinking ability [13]; Recently, Cao Peisheng has conducted an empirical study on CBI's thematic model for serving college English teaching, which has achieved good results in cultivating learning emotion and promoting comprehensive English ability [14].

Therefore, the introduction of CBI into specialized English teaching can not only encourage students to participate more actively in language activities and develop relevant skills, but also promote the improvement of specialized English teaching. 


\section{TEACHING DESIGN OF SPECIALIZED ENGLISH COURSES FOR NON- COMMISSIONED OFFICERS BASED ON CBI}

\subsection{Setting of Curriculum Objectives}

Specialized English is significantly different from professional teaching or public English teaching. The goal of specialized English teaching is to improve the students' ability of listening, speaking, reading, writing and translating the English content involved in this major. Generally speaking, non-commissioned officers' specialized English teaching should use English as the target language, and carry out teaching activities around the professional content, so that students can think positively and have a broad vision, and finally make adequate preparations for their future job development. To be specific, at the end of the course, students are required to understand the importance of specialized English learning, proficiently master common specialized English vocabulary, accurately read and translate English documents in professional fields, and can use the Internet, new media and other channels to obtain International frontier development trends in professional fields.

\subsection{Selection of Course Content}

Stryker \& Leaver proposed three elements of CBI. First, carry out target language teaching around subject knowledge and improve students' foreign language communicative competence in subject content teaching. Second, select real materials used by the target language speakers and use the target language to complete the subject teaching content. Third, set up teaching content and teaching topics according to the needs of students, and design teaching activities according to students' language foundation, emotional needs, personal interests, and future career needs [15].

To apply this CBI teaching concept to specialized English teaching, teaching courses should be set based on the practical needs of students, understanding students' learning habits, course expectations, professional development requirements and other practical needs, so as to improve students' professional quality as well as their application ability of professional subjects. Therefore, before, during, and after the course is opened, corresponding needs analysis should be carried out (see "Table 1") to fully understand students' needs and understand what students want to learn through this course and what to improve. Thus, the appropriate teaching content should be selected based on the analysis of the needs of students well as the professional characteristics of the school and the future professional needs of the major.

Table 1. Needs analysis for each stage

\begin{tabular}{|l|l|}
\hline \multicolumn{1}{|c|}{ Stages of needs analysis } & \multicolumn{1}{|c|}{ Needs analysis methods } \\
\hline Before the course & $\begin{array}{l}\text { questionnaire surveys, interviews, informal } \\
\text { discussions }\end{array}$ \\
\hline During the course & $\begin{array}{l}\text { Student learning performance and schoolwork } \\
\text { feedback, mid-term test results }\end{array}$ \\
\hline After the course & Final test scores, informal discussions \\
\hline
\end{tabular}

\subsection{Selection of Teaching Mode}

Among the three typical CBI teaching modes, the sheltered-content courses focus on contents more than language; the adjunct course requires both subject content and language, and requires the effective cooperation of English teachers and subject teachers; only the theme-based approach focuses more on the language used in the subject content, which is suitable for people with weak English foundation for it creates the opportunity of language training to the greatest extent. Taking into account the fact that most of the non-commissioned officers' English is not very good, this article believes that it is best to use the theme-based approach in non-commissioned officers' specialized 
English teaching. This mode has the greatest flexibility and can tailor a large number of different contents to meet the needs of learners. Therefore, in the non-commissioned officers' specialized English course, the theme-based approach is the most suitable teaching mode. The teaching module can be determined by the cognitive ability and activity ability that students should have in their major direction, and the systematic learning can be carried out according to the theme teaching content, so as to achieve the purpose of improving students' practical English application ability to meet the job demand and better adapt to the needs of the future army.

\subsection{Selection of Teaching Methods}

After determining the teaching mode, the teaching design can be carried out in accordance with the 6T teaching method proposed by Stoller. First, the teachers should determine the theme and arrange the topic. In this teaching mode, textbooks can include reading materials, listening materials, video materials and other English materials. The theme is the core content that runs through the CBI theme-based approach. Since the theme settings of each textbook are often different, the teacher should determine the appropriate theme according to the contents of the textbook. Teachers can not only develop teaching themes based on the textbooks, but also appropriately add some topics, contents and materials that students are interested in, so as to better stimulate students' interest in learning. In the CBI theme-based approach, topic is the specific expression of the theme, and the same theme can be divided into multiple topics, expounding the theme from different aspects. During the teaching process, teachers can determine the topic of each lesson according to the teaching progress, textbook content, students' English level, etc., in order to better quantify the teaching process. Second, the teachers should clarify tasks by threads. In the theme-based approach, threads can connect different topics and different parts of the same topic to ensure the continuity and integrity of English classroom teaching. In the CBI theme-based approach, the tasks and content can be combined together and the classroom teaching can be promoted based on the content, so as to avoid excessive emphasis on learning tasks and neglecting professional knowledge learning. Third, assign homework to reinforce the theme. At the end of each teaching topic, teachers should assign related English homework, such as letting students state the topic in English, write small essays in
English, or let students sort out relevant literature and make a topic speech, etc., to further consolidate the learning theme.

\subsection{Design of Teaching Evaluation}

After teaching, teachers can use classroom observations and teaching feedback in each class to reflect on the entire teaching process, including:

\subsubsection{Observation}

Classroom observation is indispensable because it can provide the evaluator with hypothetical important process variables to describe classroom activities. After making the classroom observations, course designers can re-adjust the course materials and teaching methods to suit the next class of students.

\subsubsection{Evaluation During and After the Course}

The evaluation questionnaire survey during the course can facilitate fine-tuning before the end of the course. The evaluation after the course can be carried out by analyzing the output of the students, especially the results and performance of the students' final exams. Students can also be asked to review their own learning, and to keep a diary, and make notes about whether the course is difficult or not, whether they are interested in the content or not, or whether the contents are relevant to their profession or not, etc. in learning. The updated content of the diary can be regularly checked and analyzed.

\subsubsection{Students' Feedback and Teacher's Self-evaluation}

At the end of each class, it will be of great benefit for students to make classroom evaluations and give feedback to teachers in a timely manner. Informal discussions with individual students can also be used. In formal situations, such as interview, students may feel nervous. In contrast, informal discussion with individual students is a more appropriate and spontaneous way, which will help students to make a real evaluation of the course. What's more, teachers can also reflect their teaching process by filling out a self-evaluation form or work $\log$. 


\subsubsection{Students' Self-evaluation and Peer Evaluation}

It is recommended that students participate in the evaluation process themselves. Self-assessment can be carried out in the following ways, student self-checklist, peer checklist, and detect pronunciation or grammatical errors by listening to their own oral output recordings. Peer evaluation can be used as a very effective learning aid, which is especially beneficial in classes where there are a large number of students and where teachers are often overworked with grading work.

\section{CONCLUSION}

This paper reviews various theories of CBI teaching method, and discusses some major problems related to the teaching curriculum design of specialized English teaching for noncommissioned officers on the basis of empirical research on professional teaching practice. The course design of specialized English teaching for non-commissioned officers should analyze the special needs of students and their proficiency in the target language and determine the course objectives. Finally, teaching evaluation and reflection should be integrated into the post-design process to see whether or to what extent these goals have been achieved. When using the CBI themebased approach, on the one hand, teachers are required to prepare lessons carefully, play a demonstrative role, reasonably determine the plan, and promote teaching activities step by step so as to cultivate students' language ability in a vivid language situation. On the other hand, students are required to carefully preview the teaching content, consult the teaching literature, and work hard to complete the tasks assigned by the teacher, so that they can complete the learning tasks in English or express their views in English in class.

\section{AUTHORS' CONTRIBUTIONS}

Wenhui Hao wrote the manuscript, Yucheng Zhou was responsible for experimental design, Mei Song analysed data, and Shasha Wu contributed to revising and editing.

\section{REFERENCES}

[1] Ji Peiying. Curriculum setting for Specialpurpose English Based on the Framework of College English Teaching Guide, [J]. Language world, 2017 (3) : 16-21.
[2] Dupuy, B. Content-based Instruction: Can it help ease the transition from beginning to advanced foreign language classes, $[\mathrm{J}]$. Foreign language Annals, 2000(332):205-223.

[3] Wang Qiang. English Teaching Method Course [M]. Beijing: Higher Education Press, 2005:1.

[4] Kasper, I. (ed.). Content-based College ESL Instruction [M]. Mahwah, NJ: Lawrence Erlbaum Associates, 2000:76.

[5] Stephen Davies. Content Based Instruction in EFL Contexts. The Internet TESL Journal, Vol. IX, No. 2, February 2003: http://iteslj.org/.

[6] Richards, J.C. Curriculum Development in Language Teaching [M]. Cambridge: Cambridge University Press, 2001.

[7] Robinson,P.C. ESP TODAY: A Practitioner's Guide [M]. Hemel Hempstead: Prentice Hall International (UK)Ltd., 1991.[3]

[8] Dai Qingning, Lu Pan. CBI Teaching Concept and Teaching Mode, [J]. Foreign Language Teaching Abroad, 2004(4): 16-20.

[9] Stroller F, Grabe w. A six T's Approach to Content-based Instruction [A]. In Snow M.A.\&D.M. Briton. The Content-based Classroom: Perspectives on Integrating Language and Content [C]. New York: Longman, 1997:21-37.

[10] Cao Xianwen. Application of CBI Teaching Method in Teaching Chinese as a Foreign Language, [J]. Journal of Yunnan Normal University, 2005, 3(1): 8-10.

[11] Cai Yuesheng. Using the CBI Teaching Method to Improve the Professional Oral English Level of Agricultural College Students, [J]. Higher Agricultural Education, 2005(5): 69-71.

[12] Zhang Wenjun. Higher Vocational Professional English Teaching Innovation Combining CBI and Work-study, [J]. Foreign Languages World, 2008(3): 26-32.

[13] Yuan Pinghua. An Empirical Study on the Impact of Language Teaching Based on Subject Content on Students' Critical Thinking Ability, [J]. Foreign Language Circle, 2010(6): 49-55. 
[14] Cao Peisheng. Experimental Research on the Effectiveness of College English CBI Subject Teaching Model, [J]. Foreign Language Audio-visual Teaching, 2012(5): 52-55.

[15] Stryker, S.B.\& Leaver, B.L. Content-Based Instruction in Foreign language Education: Models and Methods [M]. Washington, DC: Georgetown University Press, 1997. 